\title{
GERAKAN PENGENTASAN PENGANGGURAN TERDIDIK MELALUI STRATEGI PERGURUAN TINGGI DALAM MENINGKATKAN KEWIRAUSAHAAN BAGI MAHASISWA DI PENDIDIKAN TINGGI
}

\author{
Iskandar ${ }^{1}$, Fery Sudarwadi ${ }^{2}$ \\ ${ }^{1}$ Prodi Pendidikan Matematika STKIP PGRI Sumenep, Jl. Prapaten Genteng No. 2 Bluto \\ Sumenep, 69466 Indonesia \\ ${ }^{2}$ Prodi Pendidikan Olahraga Jasmani Kesehatan dan Rekreasi, Jl. Trunojoyo Gedungan, \\ Sumenep, 69451, Indonesia
}

Email: iskandarjohar@yahoo.co.id

\begin{abstract}
ABSTRAK
Tujuan dari penelitian ini adalah untuk mengetahui strategi yang digunakan perguruan tinggi dalam meningkatkan kewirausahaan bagi para mahasiswa, termasuk untuk mengetahui visi umum kewirausahaan bagi mahasiswa. Jenis penelitian ini tergolong ke dalam penelitian deskriptif yang dikaji mendalam secara kualitatif, prosedur pengumpulan datanya diperoleh dengan menggunakan metode wawancara, dan didukung oleh dokumentasi dan observasi, kemudian data dianalisa untuk diperoleh kesimpulan dan verifikasi. Hasil penelitian menjelaskan bahwa ada beberapa strategi yang digunakan oleh STKIP PGRI Sumenep dalam kewirausahaan bagi para mahasiswa meliputi: entrepreneurship prioritiy, menyusun kurikulum dan meningkatkan SDM dosen, peningkatan produktivitas mahasiswa dan kompetensi mereka dalam dunia kerja, pendirian pusat kewirausahaan kampus, membentuk unit usaha mahasiswa, KKN-usaha, magang kewirausahaan, dan program kreatif mahasiswa, pegembangan program mahasiswa wirausaha, membentuk sentra kewirausahaan, kerjasama dengan dunia usaha dan institusi keuangan, lomba kewirausahaan, memiliki usaha sebagai syarat kelulusan mahasiswa.
\end{abstract}

Kata kunci: Kewirausahaan, Pengangguran terdidik, Strategi perguruan tinggi

\begin{abstract}
The purpose of this study are to find out what strategies were used at universities in increasing entrepreneurship for students, including to find out the general vision of entrepreneurship for students. this type of research was qualitative descriptive research, the procedure for collecting data is obtained using interview methods, and supported by documentation and observation, then the data is analyzed to obtain conclusions and verification. The results of the study explained that there were several strategies used by STKIP PGRI Sumenep in entrepreneurship for students including: prioritizing entrepreneurship, compiling curriculum and increasing lecturer HR, increasing labor competency and productivity for students, establishing campus entrepreneurship centers, forming student business units, KKN-business, entrepreneurship internship,
\end{abstract}


and student creative programs, the development of entrepreneurial student programs, forming entrepreneurship centers, cooperation with the business world and financial institutions, entrepreneurship awards, the policy of having a business as a condition for student graduation.

Key words: College Strategy, Educated Unemployment, Entrepreneurship

\section{PENDAHULUAN}

Kebijakan

pemerintah

mendorong perguruan tinggi untuk menerapkan pendidikan dan pembinaan kewirausahaan terhadap mahasiswa dalam Kemenristekdikti dewasa ini merupakan bentuk perhatian serius pemerintah dalam memajukan kewirausahaan. Seakan menjadi penawar di tengah meningkatnya angka pengangguran sarjana, kewirausahaan di pendidikan tinggi terus digalakkan dengan harapan dapat memutus tingginya arus angka pengangguran yang dihasilkan oleh pendidikan tinggi.

Berdasarkan data BPS, dibandingkan Februar 2017 angka pengangguran Universitas mengalami kenaikan dari 5,18 \% menjadi 6,31\% yakni sebesar 1,13\%. Namun, meski tidak sebesar angka pengangguran lulusan SMK dan Diploma, akan tetapi angka pengangguran lulusan universitas terus mengalami peningkatan tiap tahunnya. Menurut Dirjen Pembinaan, Pelatihan dan Produktifitas Kerja Kemanker RI Bambang Lelono pada tribunnews.com, lulusan sarjana dalam setahun mencapai 750-800 ribu orang.(https://tribun.google.co.id)

Angka ini terus menerus secara fluktuatif mengalami pertambahan dan tidak dapat terserap secara keseluruhan dalam dunia kerja sabagai pegawai atau karyawan.
Dunia usaha dan industri sangatlah terbatas tidak dapat menampung lulusan perguruan tinggi secara keseluruhan, sedangkan jumlah lulusan dan pencari kerja setiap tahun semakin bertambah, sehingga banyak dari mereka yang menganggur bahkan masyarakat menyebut mereka sebagai pengangguran terdidik. (http:/ /www.umm.ac.id)

Tingginya angka pengangguran terdidik merupakan ironi permasalahan bagi bangsa dan negara di tengah tumpuan harapan yang tinggi disematkan kepada mereka. Kehadiran mereka degan bekal ilmu pengetahuan yang mereka peroleh di bangku pendidikan seharusnya menjadi pemecah sekelumit problem bangsa dalam bidang ekonomi dengan menciptakan banyak lapangan kerja agar dapat mengentaskan angka pengangguran. Namun hal ini tidak terjadi, justru kehadiran mereka malah menjadi beban bagi negara.

Banyak faktor pendorong tingginya angka pengagguran terdidik di Indonesia. Selain terbatasnya lapangan pekerjaan di sektor formal, faktor lain dikarenakan ketidaksesuaian keahlian lulusan dengan kriteria yang dibutuhkan. Selanjutnya faktor yang tak kalah penting adalah kompetensi lulusan, sebagaimana disampaikan Penasihat Dewan Pendidikan Jawa Timur, 
bahwa dominasi penekanan pada pengajaran akademik yang diterapkan di kurikulum SI berakibat pada mental sebagian besar lulusan yang cenderung menjadi job-seeker (pencari kerja) dan tidak job-creator (pencipta pekerjaan) (www.kompasiana.com).

\section{Penerapan}

pendidikan

kewirausahaan di pendidikan tinggi diharapkan dapat memberikan solusi bagi mahasiswa dengan memberikan bekal teori dan praktik keterampilan berwirausaha agar setelah lulus dapat mengantarkan mereka menjadi sarjana yang siap menjadi job-creator (pencipta pekerjaan) dan tidak hanya menjadi job-seeker (pencari kerja). Keberadaan mereka di dunia usaha dengan bekal keterampilan wirausaha yang mereka peroleh di pendidikan tinggi, diharapkan menjadi pencipta lapangan kerja (pengusaha) atau wirausahawan yang turut serta membantu memajukan perekonomian Indonesia.

Minimnya jumlah pengusaha di Indoensia, berimplikasi pada rendanya daya saing, sehingga dibutuhkan ketersediaan lapangan yang usaha yang luas guna memunculkan daya saing yang tinggi, serta untuk terciptanya ketersediaan lapangan usaha yang luas diperlukan upaya peningkatan jumlah pengusaha. Meningkatnya jumlah pengusaha merupakan suatu indikator kemajuan ekonomi suatu negara, bahkan negara yang maju di bidang ekonomi menurut David McCleiland, minimal memiliki 2\% wirausaha dari jumlah total penduduknya, atau jika di Indonesia, dibutuhkan 4,8 juta pengusaha atau wirausaha untuk memajukan ekonomi bangsa dan negara. Berdasarkan data di negara maju sperti Amerika, terdapat lebih 12\% dari jumla total penduduknya sebagai pengusaha serta banyak yang terlibat langsung dalam kegiatan wirausaha. Di Jepang lebih dari 10\% warganya adalah pengusaha, demikian juga di negara-negara tetangga seperti Singapura dan Malaysia. Terdapat lebih dari $7.2 \%$ pengusaha Singapura dan lebih dari 3\% pengusaha Malaysia memliki andil besar dalam meningkatkan pertumbuhan ekonomi negara mereka. Kondisi ini jauh meninggalkan Indonesia yang hanya memiliki $0.18 \%$ pengusaha atau jika diprosentase bahkan kurang dari 1\% dari jumlah total penduduk yang ada. (https:// febriyanto79.wordpress.com)

Penerapan mata kuliah kewirausahaan di pendidikan tinggi di Indonesia seakan menjadi suatu keharusan untuk mencetak calon pengusaha atau wirausahawan. Menurut William Danko sebagaimana dikutip Novialumi Anita dalam jurnalnya,: "Seorang wirausahawan (entreprenuer) mempunyai kesempatan 4 kali lebih besar untuk menjadi milyuner". Pada majalah FORBES disebutkan bahwa 75\% dari 400 orang terkaya di Amerika berprofesi sebagai enterprenuer. Serta banyakya fakta yang menunjukkan bahwa banyak pengusaha sukses justru mengawali karirnya dengan memulai berwirausaha dan memulainya dari usaha kecil. (Novialumi, 2017)

Pada negara-negara maju seperti Amerika Serikat, mata kuliah kewirausahaan sudah diajarkan sejak tahun 1980-an, bahkan lebih dari 500 
sekolah sudah mengajarkan materi kewirausahaan. (Kasmir, 2016), Perguruan tinggi MIT (Massachusette Institute Technology) misalnya, tahun 1980-1996 melakukan perubahan yang cukup mengetjutkan dari semula yang arah dan core perguruan tingginya High Learning Institute and Research University menjadi Entrephreneurial University. Hal ini dipicu oleh meluasnya pengangguran terpelajar dan kurang stabilnya kondisi sosial politik dan terutama perekonomian. Meski mendapat kritik dari banyak kalangan, akan tetapi selama kurang lebih 16 tahun MIT dapat membuktikan kepada khalayak sebagai perguruan tinggi yang turut andil menghadirkan solusi terhadap tidak stabilnya kondidi perekonomian negara dengan mencetak alumnialumninya menjadi pengusaha serta mampu memunculkan kurang lebih 4 ribu perusahaan, dan menyerap 1.1 juta tenaga kerja. Prestasi dan pencapaian MIT mendapat apresiasi yang pada akhirnya menjadi percontohan yang ditiru dan diikuti oleh banyak perguruan tinggi lainya. (https://febriyanto79.wordpress.com)

Mengingat masih mudanya usia penerapan pendidikan kewirausahaan pada perguruan tinggi di Indonesia, maka diperlukan peran dan fungsi perguruan tinggi sebagai pendidik untuk lebih aktif dalam memberikan motivasi menjadi pengusaha bagi peserta didiknya. Dan dibutuhkan strategi khusus untuk mendorong percepatan peningkatan jumlah wirausaha muda terpelajar sehingga mampu berperan serta memajukan perekonomian Indonesia.
Berdasarkan paparan di atas penelitian ini memiliki beberapa tujuan, diantaranya untuk mengetahui strategi yang diterapkan oleh perguruan tinggi guna meminimalisir terjadinya pengangguran di kalangan generasi terdidik bahkan turut membantu pemerintah dalam memajukan perekonomian bangsa karena turut menciptakan generasi yang kreatif dan produktif. Selanjutnya, untuk mengetahui bentuk dan model kegiatan kewirausahaan yang diterapkan kepada mahasiswa atau peserta didik sehingga berdasarkan tujuan di atas, dijadikan rujukan oleh lembaga pendidikan atau instansi lain dalam meningkatkan program kewirausahaan bagi mahasiswa ataupun peserta didik di pendidikan tinggi.

\section{METODE}

Jenis penelitian ini tergolong ke dalam penelitian deskriptif yang dikaji mendalam secara kualitif. (Arikunto, 2006) Penelitian deskriptif dimaksudkan untuk menjelaskan visi, misi dan strategi STKIP PGRI dalam memajukan kewirausahaan bagi mahasiswa di pendidikan tinggi. Metode penelitian kualitatif menurut Bogdan dan Taylor (Moleong, 2001), adalah metode penelitian dengan data deskriptif berupa kata-kata tulisan maupun prilaku objek yang diamati.

Penelitian kualitatif yang dimaksudkan dalam penelitian ini diarahkan pada subjek penelitian secara holistik dan kontekstual. Holistik berarti dengan berada dilapangan, sehingga dengannya 
peniliti mampu memahami konteks data secara menyeluruh, dan pada akhirnya mendapatkan pandangan dan kesimpulan secara menyeluruh. Kontekstual berarti peneliti dalam penelitian ini dapat mengumpulkan dan memcatat data secara rinci terkait strategi apa saja yang dijalankan perguruan tinggi dalam mendorong kemajuan wirausaha di pendidikan tinggi.

Lokasi penelitian ini adalah Sekolah Tinggi Keguruan dan Ilmu Pendidikan Persatuan Guru Republik Indoonesia (STKIP PGRI) Sumenep. Sumber data pada penelitian ini diperoleh dari person (perorangan), place (tempat), dan paper (kertas). Sumber data berupa kata-kata dan tindakan dari civitas akademika atau stakeholder STKIP PGRI Sumenep, mulai dari Ketua, wakil ketua, dosen dan mahasiswa merupakan data person. Sedangakan data place-nya adalah STKIP PGRI Sumenep. serta paper-nya antara lain berupa buku, jurnal, majalah, data statistik, arsip administrasi dan catatan lapangan, beserta dokumen tertulis lainnya.

Prosedur pengumpulan data dilakukan melalui wawancara dengan tujuan mendapatkan informasi mengenai strategi perguruan tinggi dalam memajukan kewirausahaan serta informasi atau data apa saja yang relevan dengan penelitian ini. Selanjutnya dilakukan kajian atas berbagai dokumen yang berkaitan dengan masalah penelitian. Prosedur lainnya dalam penelitian ini dilakuakan observasi langsung terhadap objek penelitian untuk mengetahui kondisi riil objek penelitian. Adapun instrument untuk observasi yang digunakan berupa observation cheklist (lembar pengamatan).

Untuk mengetahui kesimpulan dari penelitian ini dilakukan analisis komprehensif atas data-data yang diperoleh. Hal ini menurut Burhan Bungin untuk dihhasilkan suatu kesimpulan temuan-temuan dalam penelitian perlu dibahas lebih lanjut dan pendalaman untuk mengungkap makna pada fakta. (Bungin, 2008).

\section{HASIL DAN PEMBAHASAN}

\subsection{Visi dan Misi Kewirausahaan STKIP PGRI Sumenep}

Visi umum STKIP PGRI Sumenep terhadap kewirausahaan adalah "mencetak calon pendidik yang siap berwirausaha dan mampu bersaing dengan kualitas". Sebagai LPTK yang tidak akan lepas dari core kegiatan STKIP PGRI Sumenep yaitu pendidikan dan pengajaran. Maka STKIP PGRI secara prioritas akan menyiapkan lulusan sebagai calon pendidik yang unggul kreatif dan produktif serta mampu membuka peluang wirausaha di bidang pendidikan dan pengajaran sesuai dengan program studi yang mereka pilih serta pada bidang lainnya.

Misi STKIP tentang kewirausahaan :

1) Mengubah maindset (pola pikir) mahasiswa dari kecenderungan lebih suka mencari kerja menjadi pencipta lapangan kerja melalui seminar dan bimbingan serta arahan para dosen.

2) Mempengaruhi mahasiswa untuk senantiasa aktif dan kreatif serta tidak pasif dan malas melalui 
arahan seminar dan pelatihan yang diberikan oleh dosen dan pihak perguruan tinggi.

3) Mencetak calon pendidik yang terampil dan produktif dalam berbagai bidang melalui workshop dan pelatihan yang diberikan oleh dosen maupun pihak perguruan tinggi.

\subsection{Strategi STKIP PGRI Sumenep dalam Memajukan \\ Kewirausahaan Mahasiswa di Pendidikan Tinggi}

Strategi merupakan hal penting untuk mencapai visi dan misi, sasaran maupun tujuan dari suatu program yang dicita-citakan. Dalam dunia bisnis strategi merupakan instrumen penting yang turut menunjang keberlangsungan suatu perusahaan. Tanpa strategi tertentu perusahaan akan sulit menggapai tujuan dan sasaran yang dicita-citakan. Pun dalam dunia pendidikan, untuk mencapai tujuan atau goal dari suatu program yang direncakan dibutuhkan strategi yang matang, bahkan keberadaan strategi yang terencana akan menjadikan capaian terhadap suatu yang dicita-citakan lebih efektif dan efisien.

Pada sekolah Tinggi Keguruan dan Ilmu Pendidikan PGRI Sumenep strategi memajukan kewirausahaan terus dibangun, meski tidak segalak yang dilakukan beberapa perguruan tinggi yang ada di Indonesia, strategi memajukan kewirausahaan di STKIP PGRI lambat laun terus dilakukan penyempurnaan. Hal ini dilakukan agar STKIP PGRI Suemenep turut serta menjadi perguruan tinggi yang memutus angka pengangguran terdidik.

Berikut beberapa strategi STKIP PGRI dalam memajukan kewirausahaan yang penulis petakan sebagai strategi yang telah berlangsungdan strategi yang terencana.

\subsubsection{Entrepreneurship Priority}

Mata kuliah kewirausahaan di STKIP PGRI Sumenep menjadi hal terpenting yang harus diberikan kepada mahasiswa. Bahkan, mata kuliah kewirausahaan merupakan program prioritas dari beberapa rangkaian program pendukung untuk memajukan kewirausahaan bagi mahasiswa di perguruan tinggi. Meski sebagai lembaga perguruan tinggi keguruan (LPTK) yang memiliki core kegiatan pendidikan, pengajaran dan produk ouput-nya adalah pendidik, akan tetapi STKIP PGRI Sumenep komitmen untuk memajukan kewirausahaan di pendidikan tinggi.

Dalam rangka menyiapkan lulusan yang terampil dan produktif tidak hanya di dunia pendidikan melainkan dalam dunia industri, terlebih jika nantinya dihadapkan dengan persaingan industri 4.0, STKIP PGRI Sumenep melakukan langkahlangkah progresif terhadap mahasiswa dengan diawali pemberian mata kuliah kewirausahaan ke seluruh mahasiswa program studi yang ada di kampus untuk merubah maindset dan mental para lulusan dari job seeker (pencari kerja) menjadi job creator (pencipta lapangan kerja), serta memberikan bekal keterampilan berwirausaha kepada lulusan agar 
menjadi lulusan yang produktif jika tidak terserap di dunia pendidikan.

Berdasakan hasil wawancara penulis besama pengampu mata kuliah, mata kuliah Kewirausahaan diselenggarakan dengan waktu tatap muka 150 menit ditambah dengan tugas terstruktur dan tugas mandiri. Perkuliahan dirancang untuk dilaksanakan sebanyak $14-16$ kali tatap muka atau selama satu semester. Setengah dari jadwal perkuliahan diisi dengan pemberian materi dasar bab 1 sampai dengan bab Setengah sisanya antara lain dapat diisi dengan kuliah umum dari para wirausahawan, kuliah karyawisata, tugas wirausaha.

Metode yang digunakan dalam mata kuliah Kewirausahaan di program studi pendidikan guru Sekolah Dasar STKIP PGRI Sumenep, antara lain metode karyawisata, metode ceramah yang menjelaskan teori, metode diskusi kelas, dan kuliah umum. Pada metode ceramah, Dosen pengampu mata kuliah kewirausahaan menjelaskan tentang konsep kewirausahaan meliputi: pengetian, ciri dan karakteristik wirausaha, manfaat, fungsi dan tujuan kewirausahaan, tahap-tahap memulai usaha, dan kiat menadi wirausaha yang sukses. Metode diskusi kelas juga menjadi metode yang digunakan dalam perkuliahan ini yang bertujuan untuk menyempurnakan pemahaman mahasiswa tekait konsep kewirausahaan dan beberapa kegiatan turunannya, seperti pemasaran produk dan jasa, motivasi berprestasi, kepemimpinan dalam usaha.

\subsubsection{Menyusun Kurikulum dan Meningkatkan SDM Dosen}

$\begin{array}{ccr}\begin{array}{c}\text { Sebagai } \\ \text { penerapan }\end{array} & \begin{array}{c}\text { instrumen } \\ \text { mata }\end{array} & \begin{array}{r}\text { dari } \\ \text { kuliah }\end{array}\end{array}$

kewirausahaan, STKIP PGRI Sumenep menyusun kurikulum. Dalam hal ini STKIP PGRI merancang dengan perencanaan yang baik mata kuliah kewirausahaan untuk para mahasiswa, serta merumuskan dengan sungguh-sungguh sistem atau metode pembelajaran dan pelatihan kewirusahaan dengan cara membuat SAP (satuan acara pengajaran), silabus, modul teori dan praktikum, bahkan membuat buku panduan.

Berdasarkan hasil wawancara besama pengampu mata kuliah dan temuan penulis dari dokumentasi silabus dan RPP yang mereka susun, mata kuliah ini mengacu pada buku pedoman yang dikeluarkan oleh Tim DIKTI serta rujukan dari buku referensi lainnya yang menjadi buku pendukung dari mata kuliah ini. Mata kuliah Kewirausahaan mengajarkan bagaimana mengembangkan pemahaman dan kesadaran tentang hakikat kewirausahaan yang mencakup konsep dasar, karakteristik, serta tujuan pembelajaran. Dalam mata kuliah ini mahasiswa mampu menginternalisasi nilai dan sikap yang terkandung dalam kewirausahaan, seperti etos bekerja, motif berprestasi, kemandirian, kreativitas, keterampilan pengambilan keputusan, dan sebagainya. Dalam mata kuliah ini, mengembangkan kemampuan bekerja dalam diri mahasiswa sebagai prasyarat dasar terbentuknya jiwa dan etos wirausaha, sehingga mahasiswa dapat mendiseminasikan karakteristik dan etos wirausaha secara meluas melalui jalur pendidikan formal, informal, maupun nonformal. Ruang lingkup 
yang dibahas dan didiskusikan dalam mata kuliah ini berorientasi pada dua aspek utama, yaitu orientasi nilai dan orientasi tujuan. Muatan penting dari mata kuliah ini adalah internalisasi sistem nilai yang terkandung dalam entreprneurship, yakni kemandirian, berpikir kreatif, soft-skill, keterampilan interpersonal, komunikasi persuasif, kerja keras, persistensi, dan lainnya. Pada akhirnya, dampak jangka panjang yang diharapkan dari pembentukan nilai-nilai tersebut adalah kemampuan menangkap dan mengkreasikan peluang menjadi sesuatu yang memiliki nilai jual dan nilai tambah.

Selanjutnya STKIP PGRI meningkatkan SDM dosen sebagai subjek dan sumber pengarah dan pelatih mahasiswa di bidang kewirausahaan dengan mengadakan pelatihan untuk dosen di bidang kewirausahaan yang disampaikan oleh pelatih yang kompeten. Tujuan diadakannya pelatihan bagi dosen diharapkan agar SDM Dosen lebih meningkat dan mampu menerapkan "5M", yaitu: (1) mampu menumbuhkan paradigma baru bagi mahasiswa akan pentingnya kewirausahaan. (2) mampu mengarahkan pola pikir mahasiswa menjadi seorang entrepreneurship sejati. (3) mampu memberikan motivasi dan inspirasi kepada mahasiswa agar menjadi manusia yang mandiri. (4) mampu memberikan contoh nyata berupa karya berbentuk barang maupun jasa dan menyuguhkan kiat-kiat dan kisah suksesnya. (5) mampu menelorkan lulusan mahasiswa menjadi seorang entrapreneur yang sukses.

\subsubsection{Peningkatan Produktivitas Mahasiswa dan Kompetensi Mereka dalam Dunia Kerja}

Peran aktif perguruan tinggi dalam megentaskan pengangguran terdidik dan menciptakan banyak wirausahawan tidak cukup dilakukan dengan hanya menerapkan mata kuliah kewirausahaan, program pendukung lainnya yang secara sinergis dapat menguatkan sikap dan mental mahasiswa yang diperoleh setelah mengikuti materi kuliah kewirausahaan. Program pendukung tersebut dapat berupa peningkatan kompetensi dan produktifitas mahasiswa melalui pelatihan terpusat. Sebagai perguruan tinggi yang juga memiliki komitmen untuk mengentaskan pengangguran terdidik dengan memajukan kewirausaan di kampus, STKIP PGRI Sumenep memberikan pelatihan terpusat guna meningkatkan kompetensi kerja dan produktivitas mereka, melalui Pusat Inkubator Wirausaha STKIP PGRI Sumenep (PIWS) hasil kerjasama perguruan tinggi dengan pemeritah daerah.

Melaui PIWS Pelatihan dan peningkatan produktivitas mahasiswa diberikan dalam berbagai bidang keahlian diantaranya budi daya ikan lele, batik, produksi songkok, camelan, katering, pembuatan kusen dan partisi alumunium.

\subsubsection{Pendirian Pusat Kewirusahaan Kampus}

Pusat Kewirausahaan Kampus adalah wadah dalam meningkatkan kompetensi kerja dan produktivitas mahasiswa guna mendukung mentalitas wirausaha yang mereka 
dapatkan melalaui mata kuliah kewirausahaan. Salah satu bentuk upaya serius dalam memajukan kewirausahaan di pendidikan tinggi adalah penyediaan wadah oleh kampus untuk melatih dan membekali keterampilan berwirausaha mahasiswa sebagai calon wirausahawan, yang lebih dikenal dengan pusat kewirausahaan kampus.

Pusat Inkubator Wirausaha STKIP Sumenep (PIWS) merupakan pusat kewirausahaan kampus di STKIP PGRI Sumenep. Lembaga yang berada di bawah naungan Sekolah Tinggi Keguruan dan Ilmu Pendidikan Persatuan Guru Republik Indonesia (STKIP PGRI Sumenep) didirikan dengan SK Ketua STKIP PGRI Sumenep Nomor: 92/SK/C.2/STKIP-PGRI/II/ 2016.

Melalui PIWS beraneka kegiatan telah dilaksanakan anatara lain: seminar, pelatihan, praktik usaha, kursus, loka karya, workshop, dan banyak lagi hal lainnya.

\subsubsection{Membentuk Unit Usaha Mahasiswa}

Wujud unit usaha bagi mahasiswa di perguruan tinggi merupakan salah satu bentuk nyata kesungguhan dan keseriusan perguruan tinggi dalam memajukan kewirausahaan di kampus. Dan menyongsong kesungguhan dan keseriusan dalam memajukan kewirusahaan bagi mahasiswa STKIP PGRI Sumenep mendirikan beberapa unit usaha seperti koperasi mahasiswa yang bergerak di bidang percetakan dan foto copy, kedai kopi mahasiswa yang dilengkapi fasilitas free wifi dan banyak unit kegiatan mahasiswa lainnya yang fokus hanya di bidang kewirausahaan guna memajukan kegiatan berwirausaha mahasiswa.

Berikut data unit usaha mahasiswa yang terdapat di STKIP PGRI Sumenep.

Tabel 1. Unit Usaha Mahasiswa STKIP PGRI Sumenep

\begin{tabular}{ccc}
\hline Nama Unit Usaha & Jenis Kegitan Usaha & Penanggung Jawab \\
\hline KOPMA STKIP PGRI SUMENEP & Foto Copy dan & Diana Safitri \\
& Percetakan & \\
RUMAH MAKAN ISTIMEWA & Catering & Nada Sovia \\
KEDAI KOPI SERUPUT & Kopi dan makanan ringan & Agus Mulyadi \\
TAMAN HIAS CINTA & Tanaman Hias & Sinta Pratiwi \\
BARBERSHOP CAKEP & Pangkas Rambut & Sofyan \\
RUMAH JAHIT DAN PAKAIAN & Desain, Jahit dan & Miftah \\
& Penyediaan Pakaian dan & \\
& Peralatan Kebutuhan & \\
CANGKRUK BATIK TULIS & Prodi dan Mahasiswa & Roydianto \\
RUMAH KECANTIKAN & Produksi batik tulis & Laila Fitria \\
& Salon Kecantikan dan & \\
BENGKEL LAS & Tata Hias & Umar Faruq \\
\hline
\end{tabular}




\subsubsection{Menerapkan KKN Usaha}

Strategi lain yang telah dilakukan STKIP PGRI Sumenep dalam memajukan kewirausahaan untuk mahasiswa di pendidikan tinggi adalah dengan mengadakan Program KKN Usaha. Program KKN yang dilaksanakan dengan dengan tema yang sesuaikan dengan situasi perkembangan mulai dari KKN POSDAYA, hingga KKN tematik dengan program utama yang berkaitan dengan kewirausahaan.

Dalam kegiatan program KKN kewirausahaan sebelum memberikan pelatihan kewirausahaan kepada masyarakat terlebih dahulu para mahasiswa berlatih sendiri atau mendatangkan pelatih yang kompeten untuk memproduksi suatu produk tertentu yang akan diberikan kepada masyarakat.

\subsubsection{Program Kreatif Mahasiswa (PKM)}

Strategi yang lain adalah dengan membentuk tim pembimbing yang terdiri dari dosen untuk mendorong mahasiswa dalam mengikuti Program Kreatif Mahasiswa (PKM) pada tiap program studi. PKM adalah program Kemenristek DIKTI untuk perguruan tinggi yang ditujukan agar membawa mahasiswa menjadi kreatif dan inovatif melalui penguasaan mereka terhadap sains dan teknologi saat ini. Para mahasiswa yang telah mempelajari ilmu pengetahuan dasar kewirausahaan didorong untuk memiliki ide baru sehingga mampu menciptakan produk-produk baru yang layak saing dan inovatif. Bahkan untuk mendorong minat berwirausaha mahasiswa, mereka tidak musti menciptakan sesuatu yang tidak pernah dibuat sebelumnya, melainkan didorong lebih mengembangkan ke hal yang sudah ada. Pemakaian konsep pakai teknik amati tiru dan modifikasi bisa menjadi pilihan. Gagasan kreatif dan inovatif mahasiswa dapat dikembangkan melalui dorongan dari dosen-dosen pada program studi. Bimbingan yang bersifat sharing akan menjadi wadah diskusi efektif untuk mencari minat mahasiswa.

\subsubsection{Pengembangan Program Mahasiswa Wirausaha (PMW) STKIP PGRI Suemenep} mendorong mahasiswa untuk ikut aktif dan kompetitif mmbuat pengajuan proposal PMW guna meraih dana subsidi pemerintah untuk rencana usaha. Dan bagi mereka yang lolos dan berhasil meraih dana PMW Dikti pihak kampus memberikan reward (penghargaan) berupa tambahan subsidi dana dan sertifikat bagi mahasiswa tersebut.

Tabel 2. Daftar Penerima Dana Hibah PMW Tahun 2017

\begin{tabular}{ccl}
\hline Nama Mahasiswa & Program Studi & \multicolumn{1}{c}{ Judul PMW } \\
\hline DINI ANGRAINI & PGSD & $\begin{array}{l}\text { ESKERJASAMA (Es Krim Jamur } \\
\text { Ramuan Madura) }\end{array}$ \\
KARIMATUS SYAFAAH & PBSI & $\begin{array}{l}\text { OLET ASSU (Olet Asli Oreng } \\
\text { Sumenep) }\end{array}$ \\
\hline
\end{tabular}




\subsubsection{Magang Kewirausahaan}

Strategi selanjutnya adalah dengan mengadakan program magang Kewiraus ahaan. Melalui program ini piak kampus mendorong dosen pengampu kewirausahaan untuk mewajibkan mahasiswanya magang kewirausahaan. Hal ini dimaksdukan untuk memberikan informasi dan pengalaman kepada para mahasiswa agar belajar dan berlatih langsung kepada para pengusaha yangterdapat di lingkungan sekitar. Selain beberapa maksud di atas, program ini dimaksudkan agar dapat melatih kemampuan siswa dalam mengembangkan dan memajukan wirausahanya serta memahami risikorisiko apa saja yang akan dihadapi berikut cara pemecahannya.

Tabel 3. Daftar Magang Kewirausahaan Mahasiswa Program Studi Pendidikan Sekolah Dasar (PGSD)

\begin{tabular}{|c|c|c|}
\hline Nama Mahasiswa & NPM & Tempat Magang \\
\hline AHMAD FAWAID & 15862061A000825 & Batik Al-Barokah \\
\hline ASRI AINUN NAJAH & 15862061A000836 & Pakandangan Tengah \\
\hline ALIYA REZKI KAUSARI & 15862061A000832 & \\
\hline EMILATUR RAHMA & 15862061A000850 & \\
\hline HAIRUNNISAK & 15862061A000865 & \\
\hline ADI WIDYA PAMUNGKAS & 15862061A000824 & Batik Melati \\
\hline CHOLIFATUL ISLAMI NURUL & 15862061A000841 & Pakandangan Barat \\
\hline ENDANG KURNIAWATI & 15862061A000852 & \\
\hline FADHILATUR ROHMAH & 15862061A000854 & \\
\hline HENY ARFIAH & 15862061A000870 & \\
\hline AHMAD SUHAEDY & 15862061A000827 & Batik Canteng Koneng \\
\hline DITA SOVIATI LIZA & 15862061A000846 & Pangarangan Sumenep \\
\hline FADLILATUN NISA' & 15862061A000855 & \\
\hline FAHMATUL BAIDHAA & 15862061A000856 & \\
\hline HESTYANA YUNIARI PUTRI & 15862061A000871 & \\
\hline AHMAD SURIANTO & 15862061A000828 & Bengkel Las Iwan Bluto \\
\hline EDI SUTRISNO & 15862061A000848 & \\
\hline FAJRI & 15862061A000858 & \\
\hline HENDRI IRAWAN & 15862061A000869 & \\
\hline IDRIS & 15862061A000875 & \\
\hline IKO HARDIANSYAH & 15862061A000876 & Bengkel Las Ardi \\
\hline ILHAM CHOIRUL FATAH & 15862061A000877 & Saronggi \\
\hline MOHAMMAD ARDYANTO & 15862061A000899 & \\
\hline MOHAMMAD ARIF HANAFI & 15862061A000900 & \\
\hline MOHAMMAD FAISAL JUFRI & 15862061A000901 & \\
\hline ANDRI & 15862061A000833 & Ternak dan Pengemasan \\
\hline MOH HOLIS & 15862061A000894 & Madu Saronggi \\
\hline MOH. RIFKI & 15862061A000898 & \\
\hline LUTFI DWI YULIANA & 15862061A000888 & \\
\hline MARIYA ULFA & 15862061A000891 & \\
\hline ARI PURNOMO AJI & 15862061A000835 & Ternak dan Pengemasan \\
\hline IMAM GUSYAIRI & 15862061A000878 & Madu Lenteng \\
\hline HUSNUL HOTIMA & 15862061A000874 & \\
\hline MUHAMMAD ROMLI & 15862061A000902 & \\
\hline MUTAWAKIL ALALLAH & 15862061A000903 & \\
\hline
\end{tabular}




\begin{tabular}{ccc}
\hline \hline BADRUL FALAH & 15862061A000838 & Jatem Tailor Parsanga \\
DESI WULANDARI & 15862061A000843 & Sumenep \\
FAIQOTUL 'ATHIYYAH & 15862061A000857 & \\
FATHINIL UMANAH & 15862061A000859 & \\
ITA NURMALASARI & 15862061A000884 & \\
BAHARUDIN & 15862061A000839 & Irwan Tailor Batuan \\
BASTIAN & 15862061A000840 & Sumenep \\
GITA NURUL AZMI & 15862061A000863 & \\
HAFIDA FITRIYA & 15862061A000864 & \\
IRENA FITRIANDINI & 15862061A000882 & \\
\hline
\end{tabular}

1.2.10 Membentuk Pusat atau Sentra Kewirausahaan.

Program entrepreneurship center akan melengkapi beberapa unit kegiatan mahasiswa yang sudah ada di STKIP PGRI sebagai bentuk organisasi mahasiswa yang secara khusus fokus untuk memacu dan memajukan program kewirausahaan di pendidikan tinggi.

\subsubsection{Kerjamasa Peguruan Tinggi dengan Dunia Usaha.}

Dalam rangka memajukan kewirausahaan, pnting bagi perguruan tinggi untuk bekerjasama dengan dunia usaha. Kerjasama ini dapat dibangun dengan sistem simbiosis mutualism, sama-sama memberikan keuntungan terhadap kedua belah pihak antara kampus dan dunia usaha. Di satu sisi pihak dunia usaha bisa menjadi konsultan bagi kampus dalam memberikan informasi tentang dunia usaha sehingga dapat meningkatkan kualitas SDM para mahasiswa dan dosen. Selanjutnya menjadi tempat magang usaha mahasiswa atau bahkan dosen, serta pada sisi yang lain, dunia usaha dapat diuntungkan dengan menampung hasil produksi mahasiswa/alumni dan dosen untuk kemudian menambah kuantitas produksi mereka.

Berikut data hasil rekap penulis bentuk kerjasama STKIP PGRI Sumenep bersama beberapa perusahaan.

Tabel 4. Hasil Rekap Penulis Bentuk Kerjasama STKIP PGRI Sumenep

\begin{tabular}{ccc}
\hline Nama Badan Usaha & Bentuk Kerjasama & $\begin{array}{c}\text { Tahun } \\
\text { Mulai }\end{array}$ \\
\hline Batik Tulis Al-Barokah & Magang Kewirausahaan Mahasiswa & 2014 \\
Pakandangan & (Desain gambar dan batik) & \\
Batik Tulis Canteng Koneng & Magang Kewirausahaan Mahasiswa & 2015 \\
Kota Sumenep & (Desain gambar dan batik) & \\
Catering Kartini & Kerjasama Usaha Kuliner & 2014 \\
Catering Mbak Yuni & Kerjasama Usaha Kuliner & 2015 \\
Jatem Tailor & Magang Kewirausahaan Mahasiswa & 2017 \\
Hidayat Tailor & (desain dan jahit pakaian) & \\
& Magang Kewirausahaan Mahasiswa & 2017 \\
Bengkel Motor Mitra Setia & (desain dan jahit pakaian) & \\
Agung Sumenep & Magang Kewirausahaan & 2016 \\
Bengkel Motor Iwan Bluto & Magang Kewirausahaan & 2016 \\
\hline
\end{tabular}




\begin{tabular}{ccc}
\hline CV Jamu Tradisional Pak Kumis & Magang Kewirausahaan & 2018 \\
Sumenep & Magang Kewirausahaan & 2018 \\
Home Industri Camilan & & \\
\hline
\end{tabular}

\subsubsection{Bekerjasama dengan lembaga keuangan.}

Guna merealisasikan rencana berwirausaha mahasiswa di pendidikan tinggi dengan baik dibutuhkan akses permodalan yang kuat, dengan modal akan memberikan kemudahan bagi mahasiswanya dalam membuka usaha, dan pendidikan tinggi dalam hal ini menjadi mediator yang dapat menghubungkan mahasiswa dengan lembaga keuangan dalam mengakses permodalan dalam bentuk kredit usaha bagi mahasiswa. Hal ini dapat memudahkan mahasiswa yang semula memiliki keterbatasan akses prmodalan unrtuk memulai bahkan mengembangkan usaha mereka.

Berikut hasil temuan penulis bentuk kegiatan kerjasama kampus dengan beberapa lembaga keuangan.

Tabel 5. Hasil Temuan Penulis Bentuk Kegiatan Kerjasama Kampus Dengan Beberapa Lembaga Keuangan

\begin{tabular}{|c|c|c|}
\hline $\begin{array}{l}\text { Nama Lembaga } \\
\text { Keuangan }\end{array}$ & Bentuk Kerjasama & Tahun Mulai \\
\hline $\begin{array}{l}\text { Bank Negara Indonesia } \\
\text { (BNI) } \quad \text { Cabang } \\
\text { Sumenep }\end{array}$ & $\begin{array}{lr}\text { Pembayaran } & \text { SPP dan } \\
\text { Pembiayaan } & \text { program } \\
\text { kegiatan } & \text { usaha } \\
\text { kampus } & \end{array}$ & 2013 \\
\hline $\begin{array}{l}\text { Bank Pembiayaan } \\
\text { Rakyat Syariah (BPRS } \\
\text { Bhakti Sumekar }\end{array}$ & $\begin{array}{l}\text { Pembiayaan Kegiatan } \\
\text { Usaha Kampus }\end{array}$ & 2015 \\
\hline $\begin{array}{lr}\text { Koperasi } & \text { Simpan } \\
\text { Pinjam STKIP PGRI } \\
\text { Sumenep }\end{array}$ & $\begin{array}{l}\text { Pembiayaan Kegiatan } \\
\text { Usaha Kampus }\end{array}$ & 2017 \\
\hline
\end{tabular}

\subsubsection{Menyelenggarakan Lomba Kewirausahaan.}

Salah satu upaya untuk meningkatkan atmosfir semangat berwirausaha di kalangan mahasiswa antara lain dengan diseleggarakannya kejuaraan di bidang kewirausahaan. Hal ini bisa dilakukan dalam bentuk penilaian bussiness plane (Perencanaan
Bisnis) atau entrepreneurship expo dan lain sebagainya dengan memberikan penghargaan bagi mahasiswa yang berprestasi di bidang tersebut serta memberikan insentif untuk untuk merealisasikan dan mengembangkan usaha mereka. 
Tabel 6. Lomba Kewirausahaan yang Dilakukan oleh STKIP PGRI Sumenep Dua Tahun Terakhir 2017-2018

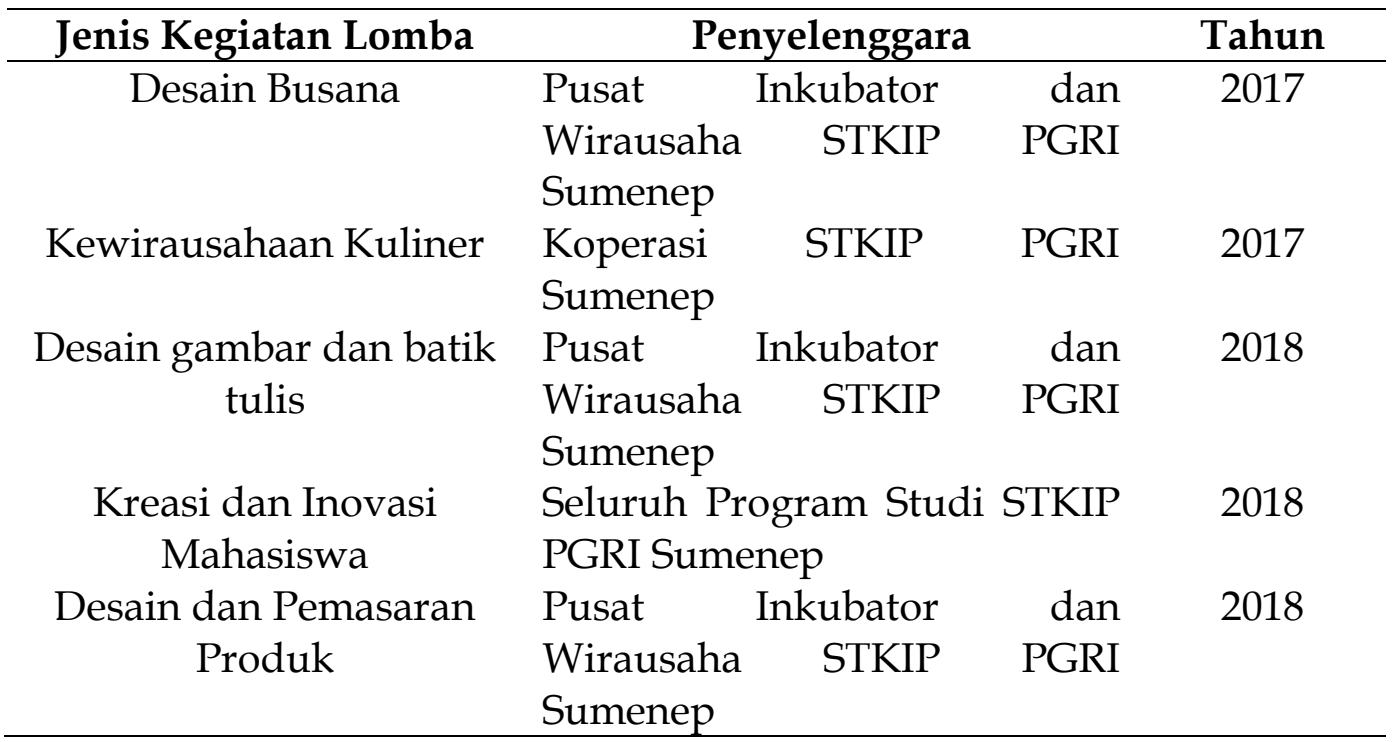

\subsubsection{Mahasiswa harus usaha sebagai kelulusan}

Memberlakukan kebijakan

memiliki usaha sebagai syarat kelulusan bagi mahasiswa merupakan strategi pamungkas yang akan diterapkan dan menurut wakil ketua bidang akademik STKIP PGRI Sumenep sangat memungkinkan untuk diterapkan jika pada saatnya sudah sangat urgent untuk diterapkan. Hal ini penting supaya lulusan STKIP yang tidak terserap di dunia kerja sudah memiliki usaha yang bisa ditekuni dan dikembangkan.

\section{KESIMPULAN}

Dalam upaya mengentaskan pengangguran terdidik di tengah meningkatnya jumlah pengangguran lulusan perguruan tinggi saat ini, beberapa upaya yang dilakukan STKIP PGRI Sumenep adalah salah satunya dengan membangun strategi dalam meningkatkan program kewiausahaan bagi mahasiswa. Beberapa strategi yang dibangun oleh STKIP PGRI Sumenep antara lain: 1. Entrepreneurship Priority (Menjadikan kewirausahaan suatu kegiatan penting dan prioritas), 2. Menyusun kurikulum dan meningkatkan SDM dosen, 3. Peningkatan produktivitas mahasiswa dan kompetensi mereka dalam dunia kerja, 4. Pendirian pusat kewirausahaan kampus, 5. Membentuk unit usaha mahasiswa, 6 . KKN-usaha, $7 . \quad$ Magang kewirausahaan, dan 8, Program kreatif mahasiswa, 9. Pegembangan program mahasiswa wirausaha, 10. Membentuk sentra kewirausahaan, 11 . Kerjasama dengan dunia usaha dan institusi keuangan, 12. Lomba kewirausahaan, 13. Memiliki usaha sebagai syarat kelulusan mahasiswa. 
DAFTAR PUSTAKA

Arikunto, Suharsimi. 2006. Prosedur

Penelitian Suatu Pendekatan

Praktik, Renika Cipta.

Burhan, Bugin. 2008. Analisis Data Penelitian Kualitatif Penguasaan Model Aplikasi Jakarta : Raja Grafindo.
Kasmir, Kewirausahaan, 2016, Jakarta, PT. RajaGrafindo Persada.

Moleong, L.J. 2001. Metodologi Penelitian Kualitatif, PT. Remaja Rosda Karya, Bandung.

Novialumi, Anita. 2017. Jurnal Parameter, Volume 2, No. 1: 5472. 